\title{
Antibacterial Activities of Green Basil (Ocimum Violaceum) Essential Oil and Derivatives By MAOS (Microwave Assisted Organic Synthesis) Against Staphyllococus Aureus and Escherichia Coli
}

\author{
Dwiarso Rubiyanto ${ }^{1}$, Hady Anshory ${ }^{2}$, Hardjono Sastrohamidjojo ${ }^{3}$ \\ dan Chairil Anwar ${ }^{3}$ \\ ${ }^{1}$ Jurusan Kimia, FMIPA, Universitas Islam Indonesia, Jogjakarta; \\ ${ }^{2}$ Jurusan Farmasi, FMIPA, Universitas Islam Indonesia, Jogjakarta; \\ ${ }^{3}$ Jurusan Kimia, FMIPA, Universitas Gadjah Mada, Jogjakarta \\ Email korespondensi:dwiarso@uii.ac.id
}

\begin{abstract}
Green basil (Ocimum violaceum, Linn.) plantis part of the varieties of basil (Ocimum basilicum, Linn.). Green basil essential oil (GBEO) contain chemical compounds that have an anti- bacterial activities. Methyl eugenol and methyl chavikol are in green basil oil has the potential to be used as a material which is biologically active. Conversion reaction of the compounds in GBEO with MAOS methods (microwave assisted organic synthesis) aims to obtain properties of the main chemical component in a wider sweet basil oil, and are also useful in an attempt to gain more valuable compounds for commercial and higher. The results showed that the optimum reaction conditions on the conversion reaction of compounds in GBEO with MAOS method with ethylene glycol as a solvent is $10 \% \mathrm{KF} / \mathrm{Al}_{2} \mathrm{O}_{3}$ as catalyst and reaction time 3 minutes, while the solvent is glycerol $10 \%$ $\mathrm{KF} / \mathrm{Al}_{2} \mathrm{O}_{3}$ as catalyst and reaction time 2 minutes . Comparison of anti-bacterial activity resulting from this research are : the inhibitory activity to the growth of S. aureus bacteria have the following order : GBEO > green basilEG10-3 > green basil G10-2> amoxicillin with each inhibition zone diameter amounted to $30.7 \mathrm{~mm}, 21.1 \mathrm{~mm}, 18.2 \mathrm{~mm}$ and $13.4 \mathrm{~mm}$. While the inhibitory activity to the growth of E.coli bacteria are : GBEO > green basil G10-2 > green basil EG10-3 > amoxicillin with each inhibition zone diameter of $21.1 \mathrm{~mm}, 15.6 \mathrm{~mm}, 15.2 \mathrm{~mm}$ and $7.9 \mathrm{~mm}$. GBEO and its derivatives have minimal inhibitory concentrations below $1.25 \%$. From the results of the study found that the main derivates obtained are p-methoxy anisaldehyde, caryophyllene oxide , 3-methoxy cinnamaldehyde, humulena oxide and delta cadinol .
\end{abstract}

Key Words: essential oils, green basil, anti-bacteria, S. aureus, E. coli, MAOS

\section{ABSTRAK}

Tanaman selasih hijau (Ocimum violaceum, Linn.) merupakan bagian dari varietas selasih (Ocimum basilicum, Linn.).Tanaman selasih hijau mengandung senyawa-senyawa kimia yang bersifat anti bakteri.Senyawa metil kavikol dan metil eugenol dalam minyak selasih hijau memiliki potensi untuk digunakan sebagai bahan yang bersifat aktif secara biologi. Reaksi konversi senyawa dalam minyak selasih hijaudengan metode MAOS (microwave assisted organic synthesis) bertujuan untuk mendapatkan sifat komponen kimia utama dalam minyak selasih yang lebih luas, juga bermanfaat dalam upaya untuk mendapatkan senyawa yang lebih bernilai guna dan komersial lebih tinggi. Hasil penelitian menunjukkan bahwa kondisi reaksi yang optimum pada reaksi konversi senyawa dalam tanaman selasih hijau dengan metode MAOS dengan pelarut etilen glikol adalah katalis $\mathrm{KF} / \mathrm{Al}_{2} \mathrm{O}_{3} 10 \%$ 
dan waktu reaksi 3 menit, sementara dengan pelarut gliserol adalah katalis $\mathrm{KF} / \mathrm{Al}_{2} \mathrm{O}_{3} \quad 10 \%$ dan waktu reaksi 2 menit. Perbandingan aktivitas anti bakteri yang dihasilkan dari penelitian ini adalah : aktivitas penghambatan pertumbuhan bakteri S.aureus memiliki urutan sebagai berikut : minyak selasih hijau $>$ selasih hijau 10-3-EG > selasih hijau 10-2-G > amoksisilin dengan diameter zona hambat masingmasing sebesar $30,7 \mathrm{~mm} ; 21,1 \mathrm{~mm}, 18,2 \mathrm{~mm}$ dan $13,4 \mathrm{~mm}$. Sementara aktivitas penghambatan pertumbuhan bakteri E.coli. adalah : minyak selasih hijau $>$ selasih hijau 10-2-G $>$ selasih hijau 10-3EG $>$ amoksisilin dengan diameter zona hambat sebesar 21,1 mm; 15,6 mm, 15,2 $\mathrm{mm}$ dan 7,9 mm. Minyak selasih hijau dan derivatnya memiliki konsentrasi hambat minimal di bawah 1,25\%. Dari hasil penelitian ditemukan bahwa senyawa turunan utama yang diperoleh antara lain senyawa $p$ metoksi anisaldehida, karyofilena oksida, 3-metoksi sinamaldehida, humulena oksida dan delta kadinol.

Kata kunci : minyak atsiri, selasih hijau, anti bakteri, S.aureus, E. coli, MAOS

\section{Pendahuluan}

Saat ini penyakit infeksi masih menjadi masalah serius di Indonesia. Lebih dari $45 \%$ terjadi kematian di Negara ASEAN adalah akibat penyakit infeksi. Salah satu penyebab penyakit infeksi yang paling banyak menimbulkan kematian adalah bakteri (WHO, 1998). Hal tersebut mendorong pentingnya penggalian sumber obat-obatan antibakteri yang potensial yang berasal dari bahan alam seperti penggunaan tanaman obat dan minyak atsiri Indonesia.

Selasih hijau (Ocimum violaceum, L.) merupakan satu keluarga dengan kemangi dan selasih pada umumnya (Ocimum basilicum, L.) serta mempunyai varietas atau forma yang sangat banyak hingga ratusan, sehingga sulit dibedakan dari bentuk dan morfologinya saja (Hadipoetyanti dan Wahyuni, 2008; Rubiyanto, D., 2009). Di luar negeri, spesies Ocimum dikembangkan secara komersial dan banyak dibudidayakan seperti di Eropa bagian
Selatan, Mesir, Maroko, dan California (Chalchat dan Ozcan, 2008; Simon, et.al., 1990). Sebenarnya tanaman selasih merupakan tanaman yang memiliki banyak manfaat secara langsung antara lain : sebagai obat, pestisida nabati, penghasil minyak atsiri, sayuran dan minuman penyegar (Hadipoentyanti dan Supriadi, 2000; Kardinan, 2003; Telci, et. al., 2006; Ismail, 2006).

Dalam penelitian ini dilakukan suatu rangkaian tahapan reaksi utama berupa isomerisasi metil kavikol. Reaksi konversi bertujuan untuk mendapatkan sifat komponen kimiadalam minyak selasih hijau yang lebih luas manfaatnya (Simon, et.al., 1990; FFHPV Consortia, 2005).

Tahapan reaksi yang digunakan adalah melalui MAOS (microwave assisted organic synthesis). Penggunaan teknik irradiasi microwave merupakan salah satu cara yang menawarkan kecepatan dan efisiensi bahan dalam proses isomerisasi dan 
epoksidasi alkena dalam komponen minyak atsiri (Kappe, 2004; Kappe, et. al., 2009; Luu, et.al., 2009). Selanjutnya senyawa hasil konversi dengan metode MAOS diuji aktivitas anti bakterinya. Pengujian aktivitas senyawa kimia terhadap bakteri yang menimbulkan penyakit-penyakit infeksi seperti Staphyllococus aureus (S. aureus) dan Escherichia coli (E. coli) merupakan salah satu upaya untuk mengatasi penyebab timbulnya masalah penyakit infeksi.

\section{Tujuan Penelitian}

Penelitian ini bertujuan sebagai berikut :

1. Memperoleh kondisi reaksi yang optimum untuk mendapatkan produk turunan minyak selasih hijau dengan metode MAOS (micro wave assisted organic synthesis).

2. Mengaplikasikan sifat antibakteri minyak atsiri selasih hijau terhadap bakteri S. Aureus dan E. Coli.

3. Mengaplikasikan sifat antibakteri produk turunan minyak atsiri selasih hijau yang diperoleh dari reaksi dengan metode MAOS terhadap bakteri S. Aureus dan E. Coli.

\section{Metode Penelitian}

Alat dan bahan

Alat

Alat-alat yang akan digunakan dalam penelitian : oven Microwave 800
Watt, alat-alat gelas laboratorium, kromatografi gas GC SHIMADZU 5890, kromatografi gas-spektroskopi massa merk QP2010S SHIMADZU, spektrofotometer FTIR merk NICOLET AVATAR, seperangkat alat uji bakteri, alat fotografi dan alat analisis merk Interscience seri SCAN 500 .

\section{Bahan}

Bahan-bahan yang akan digunakan dalam penelitian terdiri atas :

Bahan-bahan untuk sintesis produk turunan minyak selasih hijau : minyak selasih hijau hasil distilasi uap, minyak selasih hijauperdagangan merk Aldrich, etilen glikol p.a. dari Merck, gliserol p.a. dari Merck, KF p.a. dari Merck, $\mathrm{Al}_{2} \mathrm{O}_{3}$ dari Merck, $\mathrm{HCl}$ p.a. dari Merck, n-heksana p.a., dietil eter p.a., kertas $\mathrm{pH}$ universal, air de-ionisasi dan akuades. Bahan-bahan untuk uji antibakteri: strain bakteri Staphylococcus aureus (S. aureus) ATCC dan Escherichia coli (E. coli) ATCC yang dibiakkan dari laboratorium mikrobiologi UII, nutrient agar (NA), nutrient broth (NB), amoksisilin, akuades.

\section{Cara Penelitian}

\section{Konversi senyawa utama minyak selasih} hijau melalui metode MAOS

Sejumlah volume tertentu pelarut (etilen glikol, gliserol) dengan perbandingan 0,6 $\mathrm{mL}$ untuk setiap gram 
$\mathrm{KF} / \mathrm{Al}_{2} \mathrm{O}_{3}$ dimasukkan ke dalam tabung reaksi (tinggi,t $=17 \mathrm{~cm}$, diameter, $\mathrm{d}=2,5$ $\mathrm{cm}$ ) yang terbuat dari kaca pyrex yang telah berisi $\mathrm{KF} / \mathrm{Al}_{2} \mathrm{O}_{3}$. Volume total campuran bahan tidak boleh melebihi 15\% tinggi tabung. Kemudian reaktan standar metil kavikol dimasukkan dengan perbandingan 1:4 terhadap $\mathrm{KF} / \mathrm{Al}_{2} \mathrm{O}_{3}$. Daya diatur mulai dari yang terendah (posisi LOW) dan dioptimasi waktu reaksinya selama 2, 3, 4, 5 dan 6 menit. Setiap selesai satu parameter reaksi, temperatur reaksi dicatat. Setelah pendinginan, campuran dilarutkan ke dalam $50 \mathrm{~mL}$ akuades dan dinetralkan dengan $\mathrm{HCl}$ $10 \%$ hingga $\mathrm{pH}=7$. Campuran yang diperoleh selanjutnya disaring. Residu dicuci dengan $25 \mathrm{~mL}$ petroleum eter atau nheksana. Filtrat dimasukkan ke dalam corong pisah dan ditambahkan dengan dietil eter atau n-heksana sebanyak 2 x $50 \quad \mathrm{~mL}$ kemudian digojog beberapa kali. Diperoleh dua lapisan. Fraksi dietil eter atau n-heksana dicuci beberapa kali dengan akuades kemudian dipisahkan. Ditambahkan $\mathrm{Na}_{2} \mathrm{SO}_{4}$ anhidrat ke dalam larutan dan pelarut dievaporasi. Penentuan kondisi optimum diperoleh dari hasil analisis dengan alat kromatografi gas. Kondisi reaksi yang memberikan rendemen tertinggi atau sisa reaktan paling sedikit digunakan untuk kondisi optimum reaksi terhadap sampel uji minyak atsiri selasih hijau. Produk reaksi dianalisis dengan kromatografi gasspektroskopi massa.

\section{Uji aktivitas antibakteri dengan metode difusi}

Minyak selasih hijau dan produk turunannya diuji efek antibakterinya pada dua jenis bakteri yaitu bakteri gram positif dengan Staphylococcus aureus (S. aureus) dan bakteri gram negatif dengan Escherichia coli (E. coli). Masing-masing bakteri dikultur selama 1 malam pada $37{ }^{\circ} \mathrm{C}$ dalam media nutrient agar (NA). Selanjutnya pengujian efek antibakteri menggunakan metode difusi (disc diffusion method) dari National Committee for Clinical Laboratory Standard (NCCLS) tahun 1997 dalam Hussain, et.al., 2008 dan BSAC (2011). Yaitu, sebanyak 100 $\mu \mathrm{L}$ suspensi yang berisi koloni bakteri sebesar 108 cfu (colony form units) $/ \mathrm{mL}$ bakteri disebarkan pada cawan petri yang berisi medium NA (50 mL media/cawan). Selanjutnya disk kertas berukuran diameter 6 $\mathrm{mm}$ yang diimpregnasi dengan 250 ppm minyak atsiri selasih atau produk turunannya disiapkan dan ditempatkan dalam media NA yang telah diinokulasi dengan bakteri yang dipilih. Amoxycillin digunakan sebagai kontrol positif senyawa antibiotik. Disk kertas tanpa sampel bahan aktif digunakan sebagai kontrol negatif. Cawan kemudian 
dijaga pada suhu $4{ }^{\circ} \mathrm{C}$ selama 1 jam, kemudian diinkubasi pada $37{ }^{\circ} \mathrm{C}$ selama 24 jam. Aktivitas antimikroba dihitung dengan cara mengukur diameter daerah hambatan pertumbuhan bakteri dalam milimeter antara sampel dan kontrol.

\section{Penentuan konsentrasi hambat minimal} dengan metode dilusi

Untuk menentukan konsentrasi minimal penghambatan bakteri (KHM= konsentrasi hambat minimal) atau minimum inhibitory concentration (MIC) digunakan metode macro-dilution broth susceptibility assay (BSAC, 2011). Pertama, disiapkan 6 tabung reaksi (2 tabung untuk kontrol dan 4 tabung untuk perlakuan). Kontrol positif berupa amoksisilin $10 \mu \mathrm{g}$ yang diencerkan ke dalam media nutrient broth (NB) dimasukkan ke tabung 1 dan nutrient broth yang diencerkan tanpa penambahan bahan aktif ke tabung 2. Selanjutnya dibuat pula seri pengenceran bahan uji dengan konsentrasi 1,25\%, 2,5\%, $5 \%$ dan $10 \%$ (v/v) ke dalam tabung 3 sampai 6 dari larutan induk $20 \mu \mathrm{L}$. Sesudah itu, ke dalam masing-masing tabung diinokulasikan dengan $0,1 \mathrm{~mL} \quad\left(10^{8} \mathrm{cfu} / \mathrm{mL}\right)$ bakteri Staphyllococus aureus dan bakteri Escherichia coli pada tahap berikutnya. Seluruh tabung diinkubasi pada $37{ }^{0} \mathrm{C}$ selama 24 jam.
Pengamatan dilakukan dengan melihat tabung yang menunjukkan pertumbuhan bakteri dengan dikocok pada hari berikutnya. Apabila tabung keruh maka berarti terjadi pertumbuhan jamur $(+)$, namun apabila tabung jernih maka berarti tidak terjadi pertumbuhan jamur (-). Tabung 1 dan tabung 2 digunakan sebagai pembanding kejernihan dan kekeruhan. Satu mata ose biakan dipindahkan dari tabung jernih (-) ke dalam media NB yang baru. Tabung diinkubasi pada $37{ }^{0} \mathrm{C}$ selama 24 jam.

Pada hari berikutnya, dengan cara pengamatan visual seperti sebelumnya, diamati apakah tabung menunjukkan pertumbuhan bakteri dengan dikocok. Apabila tabung keruh maka berarti terjadi pertumbuhan jamur $(+)$, namun apabila tabung tetap jernih maka berarti tidak terjadi pertumbuhan jamur (-). Analisis dilakukan dengan membuat tabulasi data pengamatan visual dan ditentukan konsentrasi minimum bahan aktif yang memberikan penghambatan pertumbuhan bakteri.

\section{Pembahasan}

\section{Komposisi kimia minyak selasih hijau}

Minyak atsiri selasih hijau yang diperoleh dari proses distilasi uap tanaman selasih hijau segar selanjutnya dianalisis menggunakan instrumentasi kromatografi 
gas-spetrometri massa (KG-SM). Gambar 1 berikut menunjukkan hasil analisis minyak selasih hijau untuk beberapa senyawa yang dianggap penting :

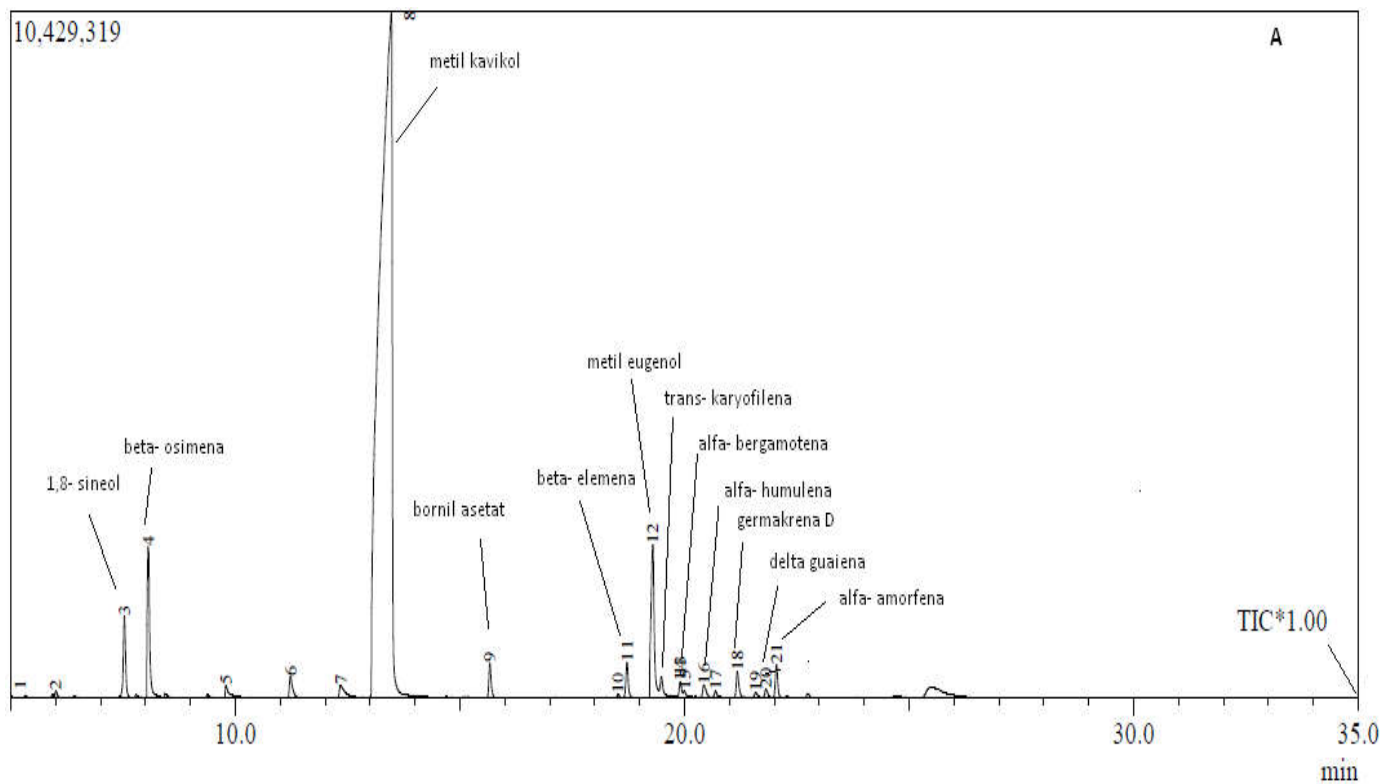

Gambar 1. Hasil analisis KG-SM minyak selasih hijau segar

Tabel 1. Komposisi kimia minyak selasih hijau

\begin{tabular}{|c|l|l|l|}
\hline \multirow{2}{*}{ No. Puncak } & \multicolumn{2}{|l|}{ Minyak Selasih Hijau } & \multirow{2}{*}{ Senyawa } \\
\cline { 2 - 3 } & $\mathbf{t}$ (menit) & \% A & \\
\hline 1. & 4,969 & 0,13 & Alfa pinena \\
\hline 2. & 6,004 & 0,10 & Beta pinena \\
\hline 3. & 7,529 & 1,98 & 1,8 -sineol \\
\hline 4. & 8,060 & 3,29 & Beta osimena \\
\hline 5. & 9,786 & 0,32 & L-linalol \\
\hline 6. & 11,228 & 0,66 & Kamfer \\
\hline 7. & 12,350 & 0,52 & Terpineol \\
\hline 8. & 13,472 & 83,04 & Metil kavikol/estragol \\
\hline 9. & 15,668 & 0,77 & Bornil asetat \\
\hline 10. & 18,519 & 0,07 & Alfa burbonena \\
\hline 11. & 18,720 & 0,86 & Beta elemena \\
\hline 12. & 19,294 & 4,90 & Metil eugenol \\
\hline 13. & 19,487 & 0,54 & Trans-karyofilena \\
\hline
\end{tabular}




\begin{tabular}{|c|l|l|l|}
\hline 14. & 19,906 & 0,36 & Alfa bergamotena \\
\hline 15. & 20,008 & 0,11 & Alfa guaiena \\
\hline 16. & 20,434 & 0,37 & Alfa humulena \\
\hline 17. & 20,694 & 0,12 & Delta kadinena \\
\hline 18. & 21,180 & 0,68 & Germakrena D \\
\hline 19. & 21,585 & 0,15 & Bisiklo germakrena \\
\hline 20. & 21,817 & 0,23 & Delta guaiena \\
\hline 21. & 22,048 & 0,81 & Alfa amorfena \\
\hline
\end{tabular}

Pada Gambar 1 dan Tabel 1, komposisi kimia minyak selasih hijau terlihat bahwa senyawa metil kavikol merupakan senyawa yang paling tinggi konsentrasinya, diikuti metil eugenol, beta osimena dan 1,8-sineol. Ini menunjukkan bahwa tanaman selasih hijau yang diteliti merupakan tipe metil kavikol. Kemo-tipe penting untuk minyak atsiri selasih hijau dapat dituliskan sebagai berikut :

metil kavikol > metil eugenol $>$ beta osimena $>1,8$-sineol

Tahapan konversi senyawa dalam minyak selasih hijau

Optimasi kondisi reaksi MAOS dengan pelarut etilen glikol (EG)

Variasi waktu reaksi
Semestinya digunakan senyawa standar metil kavikol sebagai acuan optimasi kondisi reaksi. Namun karena senyawa murni metil kavikol tidak dapat diperoleh maka digunakan senyawa dominan kedua dalam minyak selasih hijau sebagai standar yaitu senyawa metil eugenol. Persamaan reaksi perubahan metil eugenol menjadi metil isoeugenol digunakan sebagai acuan untuk menentukan perbandingan mol reaktanreaktan yang terlibat dalam konversi senyawa dalam minyak selasih hijau.

Hasil analisis menggunakan kromatografi gas (GC/FID) menunjukkan profil senyawa sebagai sebagaimana pada Gambar 3. 

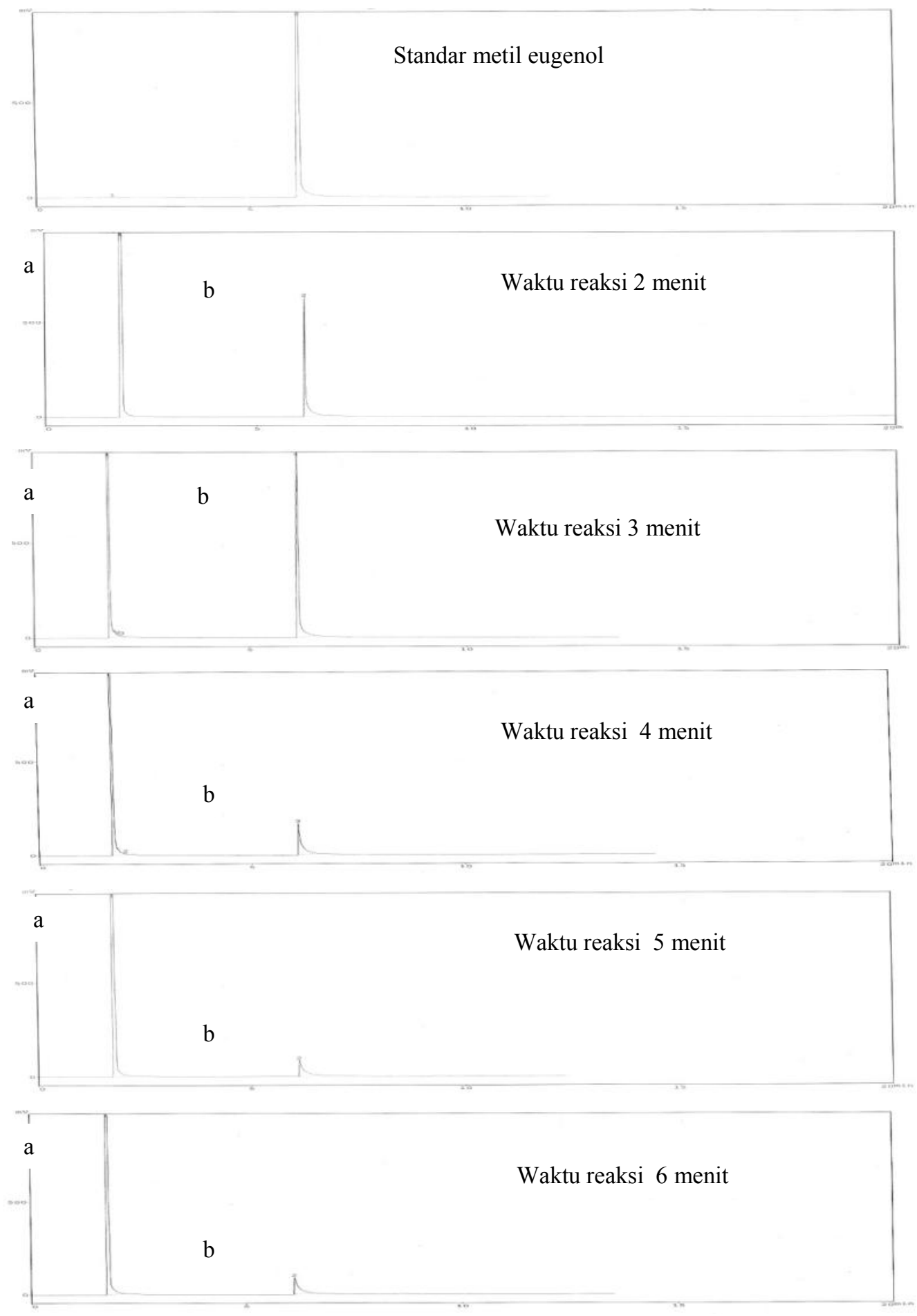

Gambar 2. Kromatogram produk berdasar variasi waktu; a. sisa pelarut etilen glikol; b. produk konversi 


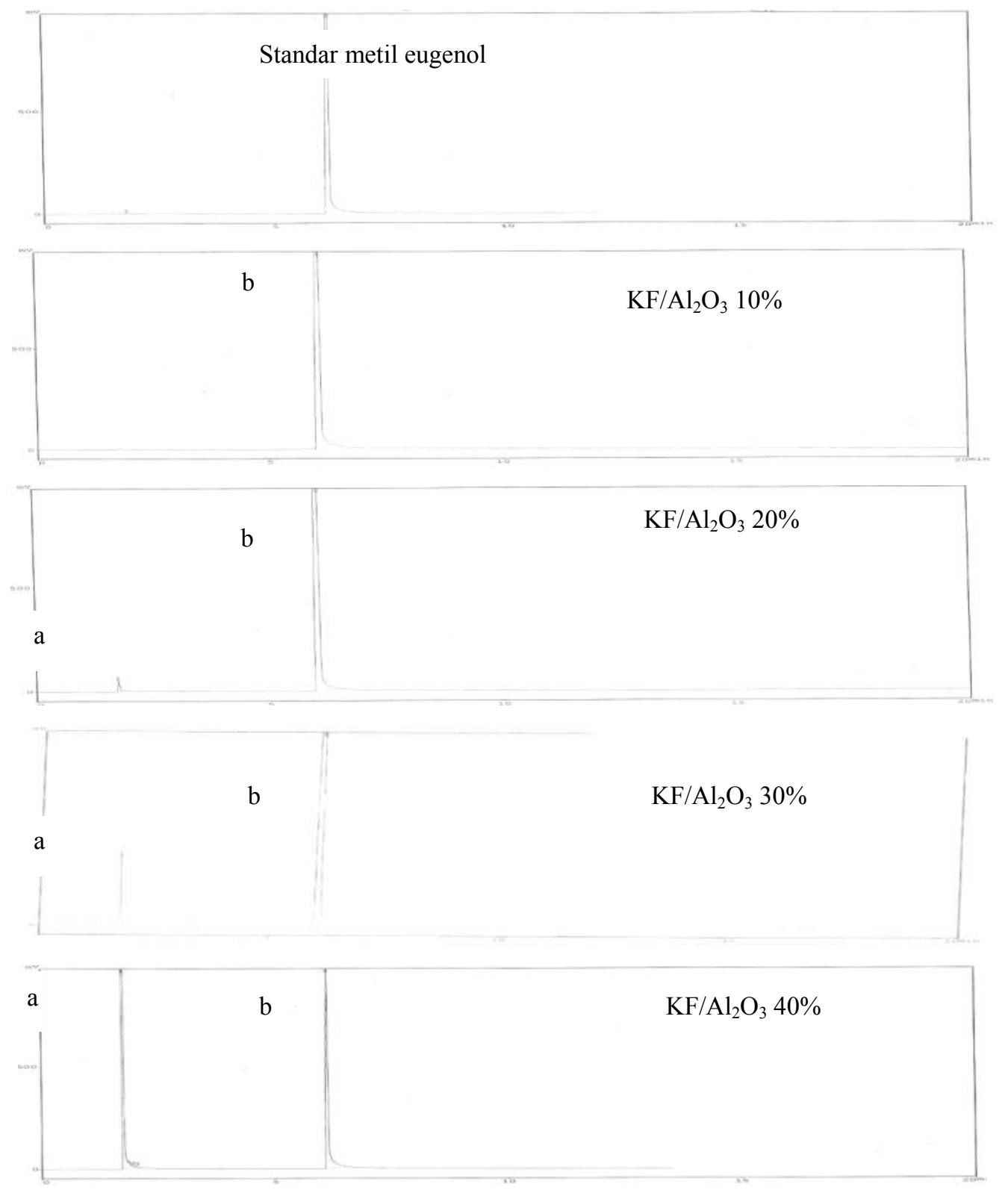

Gambar 3. Kromatogram produk berdasar variasi konsentrasi $\mathrm{KF} / \mathrm{Al}_{2} \mathrm{O}_{3}$; a. sisa pelarut etilen glikol; $b$. produk konversi

Pada penentuan konsentrasi $\quad \mathrm{KF} / \mathrm{Al}_{2} \mathrm{O}_{3} \quad$ kromatogram di atas dapat dianalisis bahwa optimal untuk reaksi isomerisasi metil konsentrasi $\mathrm{KF} / \mathrm{Al}_{2} \mathrm{O}_{3}$ yang optimal untuk eugenol dengan pelarut etilen glikol (Gambar reaksi isomerisasi metil eugenol dengan 3 ), proses penguapan pelarut sudah lebih pelarut etilen glikol adalah $10 \%$. baik dibanding sebelumnya. Hal ini terlihat Selanjutnya, kondisi waktu reaksi dan semakin kecilnya puncak pelarut yang konsentrasi $\mathrm{KF} / \mathrm{Al}_{2} \mathrm{O}_{3}$ ini digunakan sebagai terbaca pada kromatogram. Dari kondisi reaksi yang optimal. Dapat 
disimpulkan bahwa, reaksi pembentukan metil isoeugenol dengan metode MAOS dan pelarut etilen glikol berlangsung pada kondisi optimum waktu reaksi 3 menit dan konsentrasi $\mathrm{KF} / \mathrm{Al}_{2} \mathrm{O}_{3}$ sebesar $10 \%$.

\section{Kondisi optimum reaksi MAOS dengan pelarut gliserol (G)}

\section{Variasi waktu reaksi}

Dalam penentuan waktu reaksi, perbandingan mol reaktan-reaktan yang terlibat dalam reaksi isomerisasi masih sama dengan kondisi sebelumnya saat menggunakan pelarut etilen glikol. Rasio mol reaktan : katalis yang digunakan adalah $1: 2$, sementara rasio volume pelarut : berat katalis yang digunakan adalah 3:5. Variasi waktu reaksi yang digunakan : 2, 3, 4, 5 dan 6 menit.

Hasil analisis menggunakan kromatografi gas (GC/FID) menunjukkan profil senyawa sebagaimana pada Gambar 4.
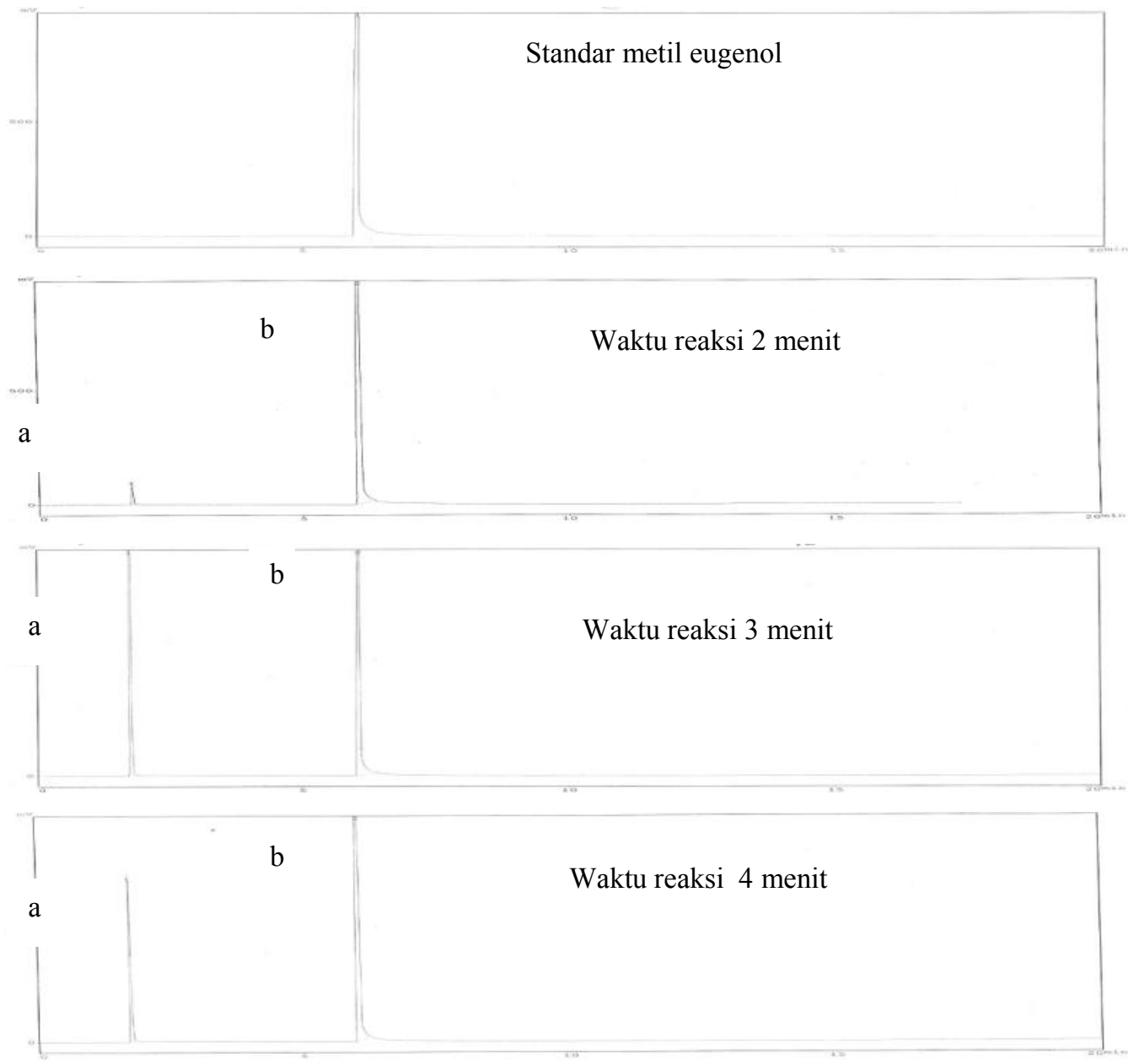


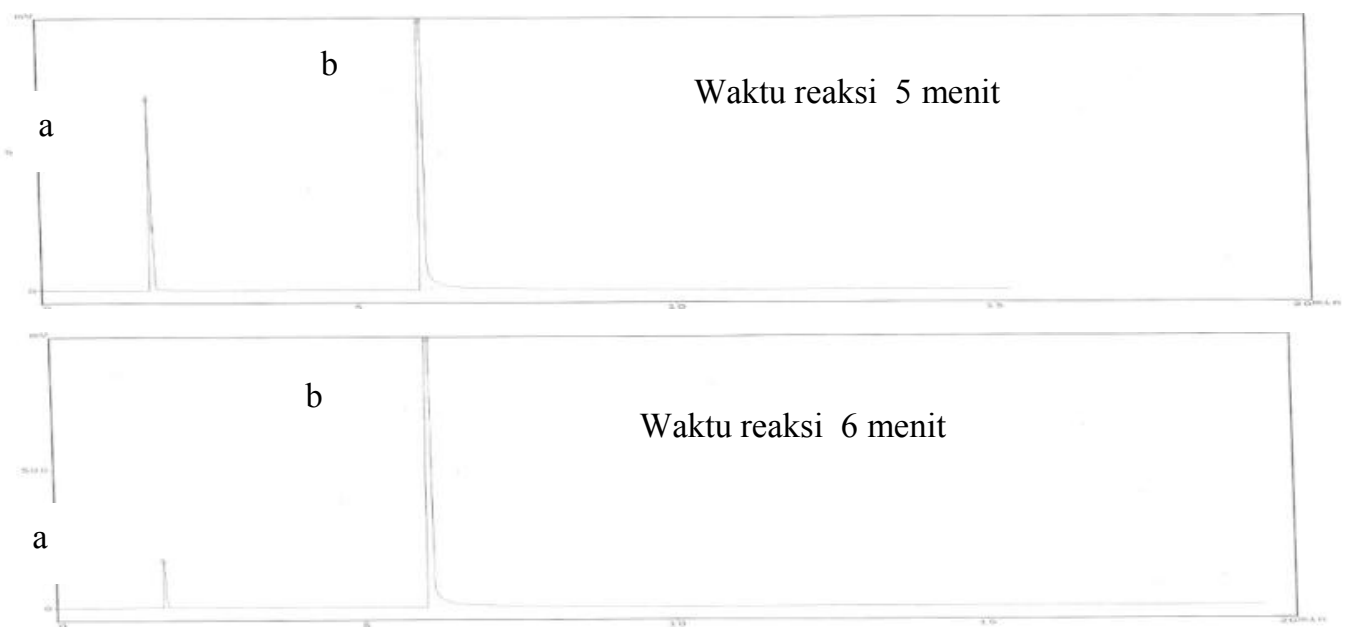

Gambar 4. Kromatogram produk berdasar variasi waktu;

a. sisa pelarut gliserol; b. produk konversi

Dari kromatogram di atas dapat dianalisis bahwa waktu reaksi yang optimal untuk reaksi isomerisasi metil eugenol dengan pelarut gliserol adalah 2 menit. Selanjutnya, kondisi waktu reaksi ini digunakan sebagai variabel dalam penentuan konsentrasi katalis $\mathrm{KF} / \mathrm{Al}_{2} \mathrm{O}_{3}$ yang optimal.
Variasi konsentrasi $\mathrm{KF} / \mathrm{Al}_{2} \mathrm{O}_{3}$

Variasi konsentrasi $\mathrm{KF} / \mathrm{Al}_{2} \mathrm{O}_{3}$ yang digunakan 10\%, 20\%, 30\% dan 40\% masingmasing sebanyak 3,3 g. Hasil analisis menggunakan kromatografi gas (GC/FID) menunjukkan profil senyawa sebagaimana pada Gambar 5.

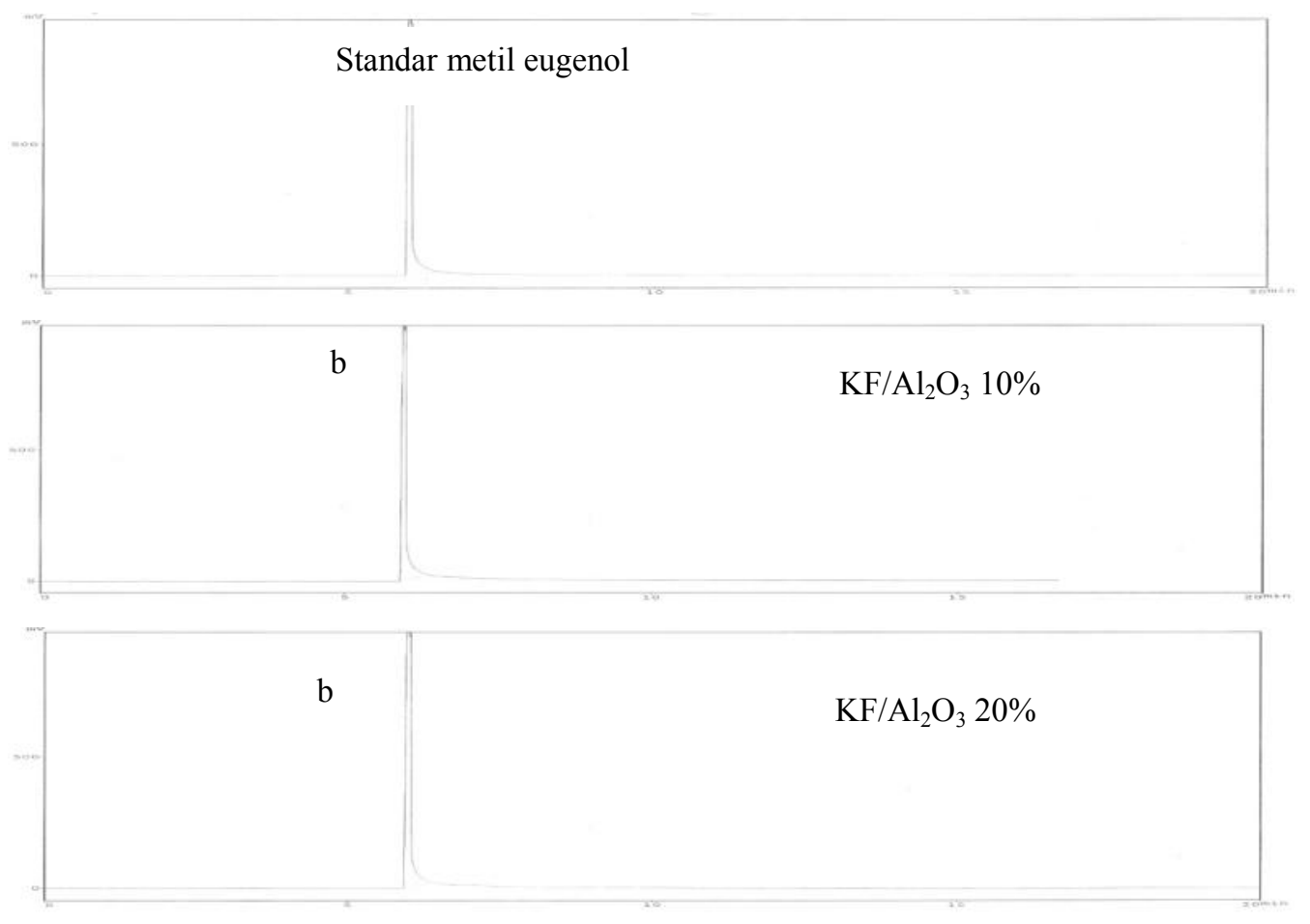

Antibacterial Activities of Green Basil (Ocimum Violaceum) Essential Oil and Derivatives...

(Dwiarso Rubiyanto, Hady Anshory, Hardjono Sastrohamidjojo dan Chairil Anwar) 


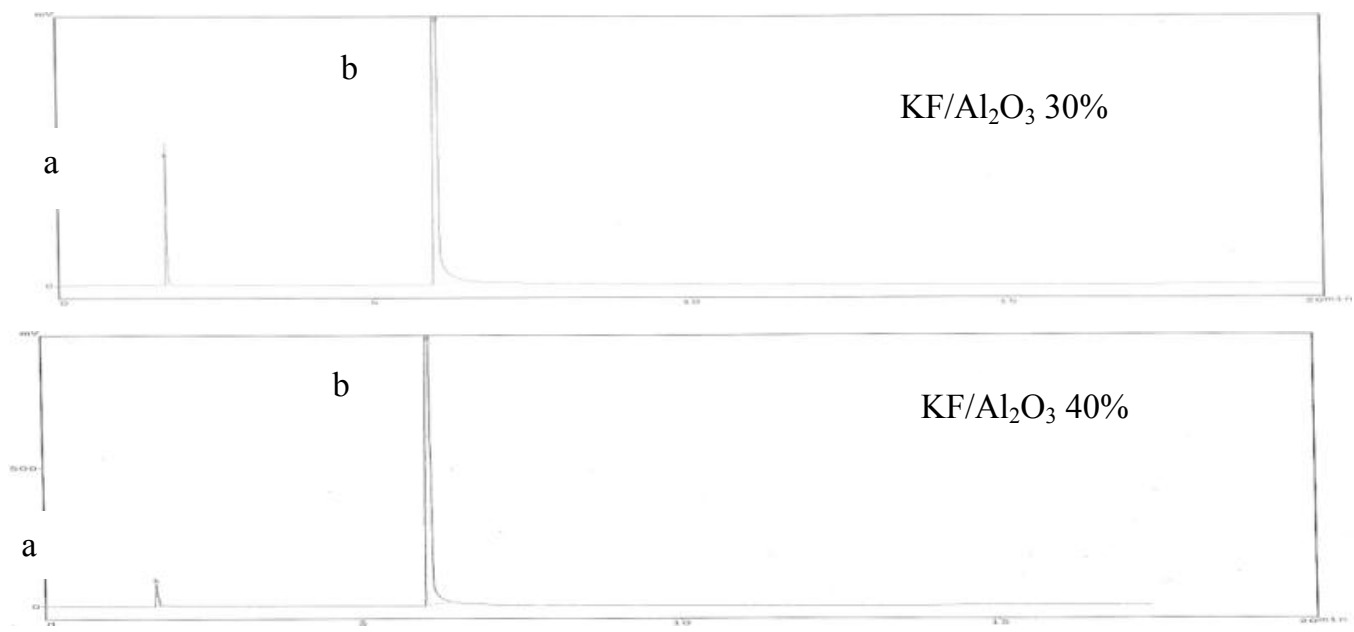

Gambar 5. Kromatogram produk berdasar variasi konsentrasi $\mathrm{KF} / \mathrm{Al}_{2} \mathrm{O}_{3}$;

a. sisa pelarut gliserol; b. produk konversi

Dari kromatogram pada Gambar 5 di atas dapat dianalisis bahwa konsentrasi $\mathrm{KF} / \mathrm{Al}_{2} \mathrm{O}_{3}$ yang optimal untuk reaksi adalah 10\%. Selanjutnya, kondisi waktu reaksi dan konsentrasi $\mathrm{KF} / \mathrm{Al}_{2} \mathrm{O}_{3}$ ini digunakan sebagai kondisi reaksi yang optimal. Dapat disimpulkan bahwa, reaksi pembentukan metil isoeugenol dengan metode MAOS dan pelarut gliserol berlangsung pada kondisi optimum waktu reaksi 2 menit dan konsentrasi $\mathrm{KF} / \mathrm{Al}_{2} \mathrm{O}_{3}$ sebesar $10 \%$.

Dari pengujian reaksi di atas, konversi senyawa minyak selasih hijau dengan metode MAOS, diperoleh kondisi optimum untuk reaksi konversi secara keseluruhan adalah sebagai berikut :

Tabel 2. Kondisi reaksi optimum untuk minyak selasih hijau

\begin{tabular}{|c|c|c|c|c|c|}
\hline Pelarut & $\begin{array}{c}\text { Konsentrasi } \\
\mathrm{KF} / \mathrm{Al}_{2} \mathrm{O}_{3}(\%)\end{array}$ & $\begin{array}{c}\text { Waktu } \\
\text { (menit) }\end{array}$ & $\begin{array}{c}\text { Daya } \\
(\text { Watt })\end{array}$ & $\begin{array}{c}\text { Kisaran } \\
\text { temperatur }\left({ }^{0} \mathrm{C}\right)\end{array}$ & $\begin{array}{c}\text { Kisaran } \mathrm{pH} \\
\text { reaksi }\end{array}$ \\
\hline $\begin{array}{c}\text { Etilen } \\
\text { glikol }\end{array}$ & 10 & 3 & Low & $70-79$ & $11-13$ \\
\hline Gliserol & 10 & 2 & Low & $68-73$ & $10-12$ \\
\hline
\end{tabular}

Pada Tabel 2 di atas terlihat bahwa konversi senyawa minyak selasih hijau dilakukan dengan variasi rasio mol reaktan : katalis yaitu $1: 2$. Sesuai kondisi reaksi seperti pada tabel, terlihat bahwa konsentrasi katalis yang digunakan sama yaitu $\mathrm{KF} / \mathrm{Al}_{2} \mathrm{O}_{3} \quad 10 \%$ dengan waktu reaksi 3 menit untuk pelarut etilen glikol dan 2 menit untuk pelarut gliserol. Dari hasil analisis kromatografi gasspektroskopi massa, diperoleh senyawa- 
senyawa produk konversi dari minyak selasih hijau seperti Gambar 6.

Hasil analisis terhadap konversi senyawa dalam minyak selasih hijau ditunjukkan pada Tabel 3. Dari Tabel 3, akumulasi hasil konversi menggunakan pelarut etilen glikol adalah sebesar 2,62\% dan akumulasi hasil konversi menggunakan pelarut gliserol adalah sebesar 4,02 \%. Beberapa produk baru yang terbentuk yaitu p- metoksi anisaldehida, karyofilena oksida, 3-metoksi sinamaldehida, humulena oksida dan delta kadinol, di mana senyawa-senyawa ini tidak dijumpai dalam minyak selasih hijau semula.

Berdasarkan kenyataan terbentuknya produk-produk tersebut dan dibandingkan dengan komposisi kimia minyak selasih hijau segar yang digunakan maka dapat disimpulkan bahwa dalam konversi dengan metode MAOS telah terjadi reaksi oksidasi terhadap beberapa komponen dalam minyak selasih hijau segar.

Aktivitas antibakteri minyak selasih dan produk konversinya terhadap bakteri Staphylococcus aureus dan Eschericia coli Dalam penelitian ini, pengujian efek antibakteri menggunakan acuan dari National Committee for Clinical Laboratory Standard (NCCLS) tahun 1997 dalam
Hussain, et.al., 2008. Uji aktivitas antibakteri minyak selasih dan turunannya menggunakan metode difusi (disc diffusion method) bertujuan untuk menentukan daya hambat terhadap pertumbuhan bakteri dan metode dilusi (dilution method) bertujuan untuk menentukan konsentrasi hambat minimal (KHM) dari bahan uji yang digunakan. Berdasarkan metode difusi akan dapat terlihat bahan uji mana yang memiliki aktivitas antibakteri paling besar, apakah bahan dalam bentuk minyak atsiri ataukah dalam bentuk turunannya. Sementara dengan metode dilusi, akan dapat ditentukan seberapa besar konsentrasi minimal bahan uji yang menghasilkan efek penghambatan pertumbuhan bakteri (BSAC, 2011).

Pada pengukuran zona hambat bakteri, media yang digunakan adalah media padat (nutrient agar) dalam cawan petri. Parameter yang dijadikan ukuran kuat tidaknya aktivitas antibakteri adalah dengan ukuran diameter zona hambat yang terbentuk. Semakin besar diameter zona hambat maka aktivitas antibakterinya semakin kuat. Kontrol positif yang digunakan adalah amoksisilin $10 \mu \mathrm{g}$, sementara kontrol negatif menggunakan blank disc berdiameter $6 \mathrm{~mm}$. Adapun hasil ujinya sebagaimana Tabel 4. 


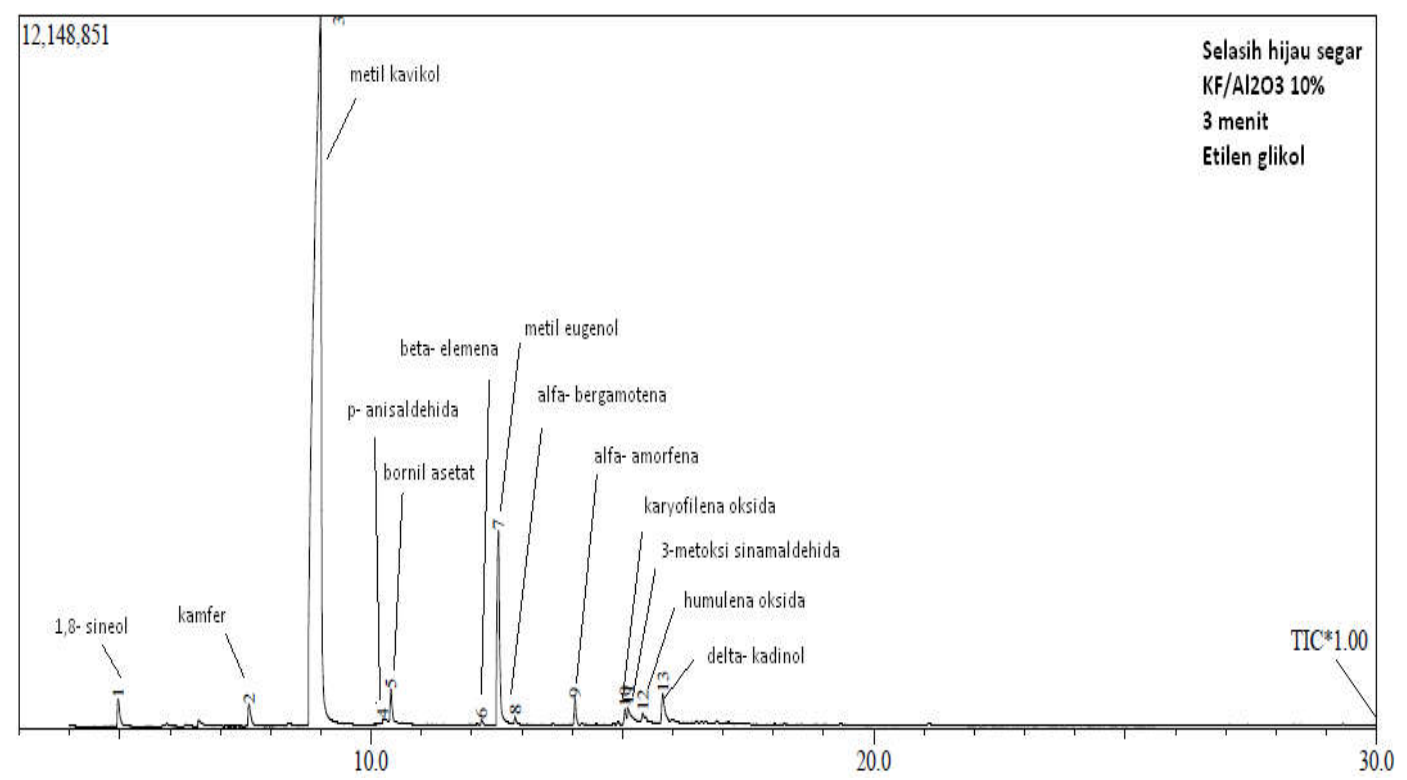

Gambar 6. Profil produk konversi minyak selasih hijau

Tabel 3. Produk MAOS dari minyak selasih hijau

\begin{tabular}{|c|c|c|c|}
\hline \multirow{2}{*}{ No. } & \multicolumn{2}{|c|}{ Senyawa uji } & \multirow{2}{*}{ Nama senyawa } \\
\cline { 2 - 3 } & SH 10-3-EG & SH 10-2-G & \\
\cline { 2 - 3 } & $\%$ & $\%$ & p-anisal dehida \\
\hline & 0,22 & $\mathrm{x}$ & Karyofilena oksida \\
\hline & 0,41 & $\mathrm{x}$ & 3-metoksi sinamaldehida \\
\hline & 0,52 & 2,00 & Humulena oksida \\
\hline & 0,15 & 0,52 & Delta kadinol \\
\hline$\Sigma=$ & 1,32 & 1,50 & \\
\hline
\end{tabular}

Keterangan :

SH 10-3-EG: $\mathrm{SH}=$ minyak selasih hijau; $\mathrm{KF} / \mathrm{Al}_{2} \mathrm{O}_{3} 10 \%$; waktu reaksi 3 menit; pelarut etilen glikol

$\mathrm{SH}$ 10-2-G: $\mathrm{SH}=$ minyak selasih hijau; $\mathrm{KF} / \mathrm{Al}_{2} \mathrm{O}_{3} 10 \%$; waktu reaksi 2 menit; pelarut gliserol

Tabel 4. Diameter zona hambat minyak selasih hijau dan produk konversinya terhadap bakteri S.aureus dan E.coli

\begin{tabular}{|c|c|c|c|c|c|c|}
\hline \multirow{3}{*}{ Sampel } & \multicolumn{6}{|c|}{ Diameter zona hambat $(\mathrm{mm})^{*}$} \\
\hline & \multicolumn{3}{|c|}{ S. aureus } & \multicolumn{3}{|c|}{ E. coli } \\
\hline & Sampel & $\begin{array}{c}\text { Kontrol } \\
(+)\end{array}$ & $\begin{array}{c}\text { Kontrol } \\
(-)\end{array}$ & Sampel & $\begin{array}{c}\text { Kontrol } \\
(+)\end{array}$ & $\begin{array}{c}\text { Kontrol } \\
(-)\end{array}$ \\
\hline
\end{tabular}




\begin{tabular}{|c|c|c|c|c|c|c|}
\hline Minyak Selasih hijau & 30,7 & 13,4 & 0 & 21,1 & 7,9 & 0 \\
\hline Selasih hijau 10-3-EG & 21,1 & 13,4 & 0 & 15,2 & 7,9 & 0 \\
\hline Selasih hijau 10-2-G & 18,2 & 13,4 & 0 & 15,6 & 7,9 & 0 \\
\hline
\end{tabular}

*diameter zona hambat diperoleh dari rata2 dari 3 kali pengujian

Kode sampel $=$ [nama bahan][konsentrasi katalis $\left.\mathrm{KF} / \mathrm{Al}_{2} \mathrm{O}_{3}\right][-][$ waktu reaksi][jenis pelarut $]$

kontrol $(+) \quad=$ Amoksisilin $10 \mu \mathrm{g}$

kontrol (-) $\quad=$ blank paper disc

Dari Tabel 4. di atas dapat disimpulkan bahwa aktivitas penghambatan pertumbuhan bakteri S.aureus dapat diurutkan sebagai berikut :

minyak selasih hijau $>$ selasih hijau 10-3-EG $>$ selasih hijau 10-2-G > amoksisilin dengan diameter zona hambat masingmasing sebesar $30,7 \mathrm{~mm} ; 21,1 \mathrm{~mm}, 18,2 \mathrm{~mm}$ dan 13,4 mm. Sedangkan aktivitas penghambatan pertumbuhan bakteri E.coli. adalah :

minyak selasih hijau $>$ selasih hijau 10-2-G $>$ selasih hijau 10-3-EG > amoksisilin dengan diameter zona hambat sebesar 21,1 $\mathrm{mm} ; 15,6 \mathrm{~mm}, 15,2 \mathrm{~mm}$ dan 7,9 mm.

Ketiga bahan tersebut menunjukkan aktivitas daya hambat yang lebih besar daripada kontrol positif yaitu amoksisilin (Gambar 5.10). Selain kandungan bahan aktif anti bakteri dalan sampel, faktor lain yang mempengaruhi besar kecilnya zona hambat dengan menggunakan metode ini adalah kemampuan difusi dari sampel itu sendiri terhadap medium yang digunakan. Apabila sampel memiliki kemampuan yang baik untuk berdifusi ke dalam media serta aktivitas antibakterinya kuat, maka zona hambat yang ditunjukkan juga besar, namun sebaliknya apabila kemampuan berdifusinya kecil ke dalam media dan walaupun aktivitasnya besar, maka zona hambat yang ditunjukkan akan lebih kecil. Oleh karena itu perlu dilakukan uji lanjutan dengan mengukur konsentrasi hambat minimalnya menggunakan metode dilusi.

Konsentrasi hambat minimal (KHM) atau minimum inhibitory concentration (MIC) adalah ukuran yang menunjukkan konsentrasi terkecil dari sampel yang dapat menghambat pertumbuhan bakteri. Metode yang digunakan dalam uji ini adalah metode dilusi (dilution method). Media yang digunakan adalah media cair (Nutrient broth) yang dicampur dengan sampel pada berbagai konsentrasi, selanjutnya ditambahkan dengan bakteri uji.

Parameter yang digunakan untuk menentukan aktivitas antibakteri dengan metode ini adalah konsentrasi terkecil dari tiap sampel pada tabung yang menunjukkan 
tidak terdapat pertumbuhan bakteri (kejernihan). Untuk menentukan jernih atau keruh dapat dilakukan dengan cara visibel atau dengan turbidimetri. Dalam penelitian ini digunakan cara visibel karena masih sangat memungkinkan dan jelas untuk dibedakan mana yang jernih dan mana yang keruh. Seri konsentrasi yang digunakan adalah konsentrasi 1,$25 ; 2,5 ; 5$; dan $10 \%$. Berikut ini adalah hasil KHM dari sampel:

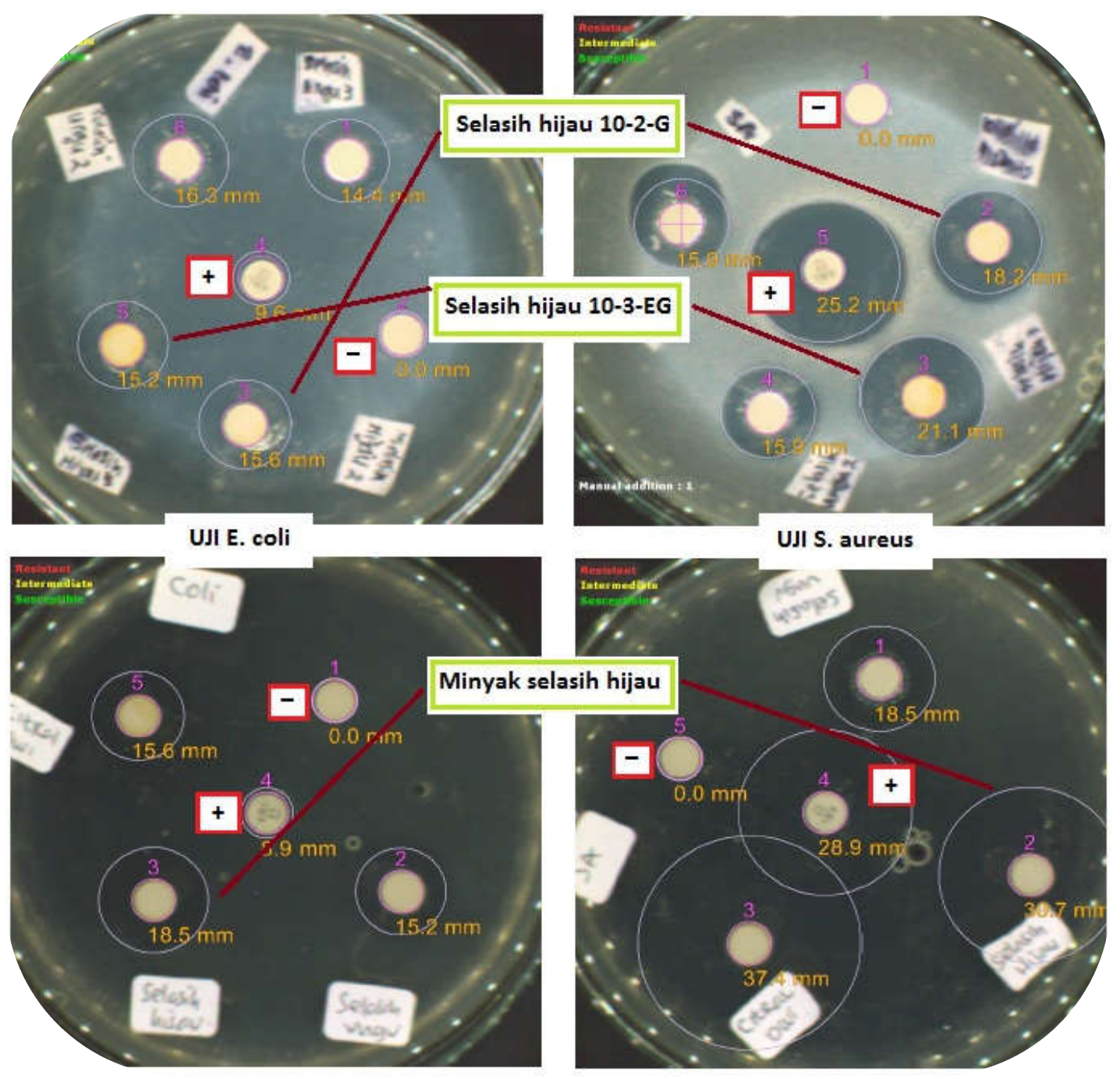

Gambar 7. Contoh hasil uji aktivitas antibakteri dari minyak selasih hijau dan produk konversinya terhadap bakteri E. coli dan bakteri S.aureus 
Tabel 5. Hasil Uji Kadar Hambat Minimal (KHM) minyak selasih hijau dan produk konversinya terhadap bakteri S.aureus dan E.coli

\begin{tabular}{|c|c|c|c|c|c|c|c|c|c|c|}
\hline \multirow[t]{2}{*}{ Sampel } & \multicolumn{4}{|c|}{$\begin{array}{c}\text { Pertumbuhan bakteri } \\
\text { S.aureus pada } \\
\text { konsentrasi }(\%)\end{array}$} & \multirow[t]{2}{*}{ KHM (\%) } & \multicolumn{4}{|c|}{$\begin{array}{c}\text { Pertumbuhan bakteri } \\
\text { E.coli pada } \\
\text { konsentrasi }(\%)\end{array}$} & \multirow{2}{*}{$\begin{array}{c}\text { KHM } \\
(\%)\end{array}$} \\
\hline & 10 & 5 & 2,5 & $\begin{array}{c}1,2 \\
5\end{array}$ & & 10 & 5 & 2,5 & $\begin{array}{c}1,2 \\
5\end{array}$ & \\
\hline Minyak Selasih hijau & - & - & - & - & $\leq 1,25$ & - & - & - & - & $\leq 1,25$ \\
\hline Selasih hijau 10-2-G & - & - & - & - & $\leq 1,25$ & - & - & - & - & $\leq 1,25$ \\
\hline $\begin{array}{c}\text { Selasih hijau 10-3- } \\
\text { EG }\end{array}$ & - & - & - & - & $\leq 1,25$ & - & - & - & - & $\leq 1,25$ \\
\hline
\end{tabular}

Keterangan :

KHM = Kadar Hambat Minimal

$+\quad=$ terjadi pertumbuhan

- $\quad=$ tidak terjadi pertumbuhan

Dari hasil uji pada Tabel 5 di atas menunjukkan bahwa ketiga bahan memberikan konsentrasi hambat minimal di bawah $1,25 \%$. Hal ini berarti pada kisaran konsentrasi yang dibuat, hanya dibutuhkan konsentrasi yang sangat kecil untuk dapat menghambat pertumbuhan bakteri $S$. aureus dan E. coli. Secara umum dapat disimpulkan bahwa baik minyak atsiri selasih hijau maupun produk turunannya memiliki daya anti bakteri yang besar terhadap pertumbuhan bakteri $S$. aureus dan E. coli.

\section{Kesimpulan}

1. Kondisi reaksi yang optimum pada reaksi konversi senyawa dalam tanaman selasih hijau dengan teknik microwave assisted organic synthesis (MAOS) dengan pelarut etilen glikol adalah katalis $\mathrm{KF} / \mathrm{Al}_{2} \mathrm{O}_{3} 10 \%$ dan waktu reaksi 3 menit, sementara dengan pelarut gliserol adalah katalis $\mathrm{KF} / \mathrm{Al}_{2} \mathrm{O}_{3} \quad 10 \%$ dan waktu reaksi 2 menit.

2. Aktivitas penghambatan pertumbuhan bakteri S.aureus dapat diurutkan sebagai berikut : minyak selasih hijau $>$ selasih hijau 10-3-EG > selasih hijau 10-2-G > amoksisilin dengan diameter zona hambat masing-masing sebesar $30,7 \mathrm{~mm}$; 21,1 mm, 18,2 $\mathrm{mm}$ dan 13,4 mm.

3. Aktivitas penghambatan pertumbuhan bakteri E.coli. adalah : minyak selasih hijau $>$ selasih hijau 10-2-G > selasih hijau 10-3-EG > amoksisilin dengan diameter zona hambat sebesar 21,1 mm; $15,6 \mathrm{~mm}, 15,2 \mathrm{~mm}$ dan $7,9 \mathrm{~mm}$. 


\section{Ucapan Terimakasih}

Tim penulis menyampaikan penghargaan dan terimakasih yang setinggi-tingginya kepada Direktorat Penelitian dan Pengabdian Masyarakat Universitas Islam Indonesia (DPPM UII) atas pemberian dana penelitian melalui skema Penelitian Unggulan.

\section{Pustaka}

BSAC (British Society for Antimicrobial Chemotherapy), 2011, BSAC Methods for Antimicrobial Susceptibility Testing, The newsletter of the British Society for Antimicrobial Chemotherapy; version 10.2, May 2011.

FFHPV Consortia, 2005, Test Plan for Estragole CAS No. 140-67-0, The Terpene Consortium, Washington DC.

Hadipoentyanti, E. dan Supriadi, 2000, Potensi Ocimum sebagai Sumber Bahan Baku Obat, Buletin Kehutanan dan Perkebunan, Vol. I, No. 1, hal. 11-19, Bogor.

Hadipoetyanti, E. dan Wahyuni, S., 2008, Keragaman Selasih (Ocimum, spp.) Berdasarkan Karakter Morfologi, Produksi dan Mutu Herba, Jurnal Littri, Vol. 14, No. 4, hal. 141-148, Bogor.

Ismail, M., 2006, Central Properties and Chemical Composition of Ocimum basilicum Essential Oil, Pharmaceutical Biology, Vol. 44,
No. 8, pp. 619-626, Informa Healthcare.

Kappe, C.O., 2004, Controlled Microwave Heating in Modern Organic Synthesis, Angew. Chem. Int. Ed., 43, $6250-6284$.

Kappe, C.O., Dallinger, D., and Murphree, S.S., 2009, Practical Microwave Synthesis for Organic Chemists: Strategies, Instruments, and Protocols, WILEY-VCH Verlag $\mathrm{GmbH} \& \mathrm{Co} . \mathrm{KGaA}$, Weinheim.

Kardinan, A., 2003, Selasih Tanaman Keramat Multimedia, cetakan pertama, Agro Media Pustaka, Jakarta.

Luu, T.X.T., Lam, T.T., Le, T.N. and Duus, F., 2009, Fast and Green Microwave-Assisted Conversion of Essential Oil Allylbenzenes into the Corresponding Aldehydes via Alkene Isomerization and Subsequent Potassium Permanganate Promoted Oxidative Alkene Group Cleavage, Molecules, 14, 3411-3424.

Rubiyanto, D., 2009, Chemical Composition Changes During Storage Of Lemon Basil Essential Oil (Ocimum Citriodorum Sp.), Prosiding International Seminar on Essential Oils (ISEO) 2009, 26-28 Oktober 2009, IPB, Bogor.

Simon, J.E., J. Quinn, and Murray, R.G., 1990, Basil: A source of essential oils. p: 484-489, Timber Press, Portland.

WHO, 1998, WHO report on Leading Infectious Killers, 
www.who.int/infectious-disease-

tanggal

10 Juni

2013.

report/page/graph5.html diakses

Antibacterial Activities of Green Basil (Ocimum Violaceum) Essential Oil and Derivatives...

(Dwiarso Rubiyanto, Hady Anshory, Hardjono Sastrohamidjojo dan Chairil Anwar) 